\title{
Nouns and pronouns in Central Lembata Lamaholot (Austronesian, Indonesia)
}

\author{
HANNA FRICKE
}

\begin{abstract}
In the past, linguists focused their studies on the description of the varieties of Lamaholot spoken in coastal communities. This article introduces Central Lembata Lamaholot, a Lamaholot variety spoken in the central mountains on the island of Lembata in the Indonesian province Nusa Tenggara Timur (NTT), which possesses features in the nominal and pronominal domains not found in other varieties of Lamaholot described so far. Alienable nouns in Central Lembata have morphological plural and specificity marking, and one sub-set of the alienable nouns has two alternating forms which are functionally different. Furthermore, free and bound pronouns in Central Lembata Lamaholot are intertwined with aspect and mood marking. The comparative analysis of these features of Central Lembata Lamaholot shows that they are partly retentions from an earlier stage of the language and partly internal innovations.
\end{abstract}

KEYWORDS

Austronesian language; Lamaholot; nominal morphology; alienability distinction; pronouns; aspect and mood.

\section{INTRODUCTION ${ }^{1}$}

This article introduces the Austronesian language Lamaholot, with a specific

1 This research was supported by the VICI research project "Reconstructing the past through languages of the present; The Lesser Sunda Islands", funded by the Netherlands Organisation for Scientific Research, project number 277-70-012. I would like to thank Owen Edwards, Marian Klamer, Francesca Moro, Nurenzia Yannuar, and an anonymous reviewer for valuable input and comments on earlier drafts of this article. Furthermore, I am grateful to Kate Bellamy for editing my English and to Owen Edwards for the fruitful discussion of my data.

HANNA FRICKE is a PhD candidate at the Leiden University Centre for Linguistics (LUCL) at Leiden University, the Netherlands. Her main research interests are descriptive linguistics, historical linguistics, Austronesian and Papuan languages in Indonesia, and language contact and change. Her most recent publication is "The rise of clause-final negation in Flores-Lembata, Eastern Indonesia", Linguistics in the Netherlands (2017): 47-62. Hanna Fricke can be contacted at: h.l.a.fricke@hum.leidenuniv.nl or hanna.fricke@gmx.de.

(C) 2017 Faculty of Humanities, Universitas Indonesia

HANNA FRICKE | DOI: 10.17510/wacana.v18i3.635. 
focus on features of Central Lembata, a previously undescribed variety of the language. The main objective of this article is to show a number of unique grammatical features of Central Lembata based on my data, collected in 2015 and 2016 in the central mountains of the island of Lembata, in the Indonesian province Nusa Tenggara Timur (NTT). My corpus of Central Lembata speech is the first extensive data collection of a Lamaholot variety in the Central Lamaholot sub-group, which covers the central and southwestern areas of Lembata.

Central Lembata Lamaholot has two sets of features which are not found in other varieties of Lamaholot, or in closely related languages: (i) a sub-set of nouns with a final coda alternation and suffixes to mark plurality or specificity, and (ii) a pronominal system incorporating aspect and mood marking. A large sub-set of Central Lembata nouns has two forms which are historically derived from each other and show an alternation in the presence or absence of the final consonant. An example is a noun for 'dog' which has the forms aor and $a u$. In this paper, this phenomenon is referred to as final coda alternation. These two forms are semantically identical, but functionally different. The comparison of these phenomena in the nominal and pronominal domains with corresponding domains in other languages of the area leads to the conclusions that in this variety the nominal system of Central Lembata Lamaholot developed independently, whereas the pronominal system seems to have been inherited from a common ancestor of all Lamaholot varieties or possibly even all Flores-Lembata languages.

This article is organized as follows. Section 2 introduces the Lamaholot dialect chain and places the language in its wider linguistic context. In Section 3 , I discuss sub-grouping within the dialect chain, while Section 4 gives an overview of the previous literature on Lamaholot. In Section 5, the main part of the article, I describe nouns and pronouns in Central Lembata Lamaholot. Section 6 takes a comparative perspective on the phenomena described and Section 7 draws conclusions.

\section{LINGUISTIC CONTEXT}

Lamaholot is best characterized as a dialect chain or dialect cluster belonging to the Malayo-Polynesian branch of the Austronesian family. Its varieties are spoken by around 180,000 people (Lewis, Simons, and Fennig 2016) living on the eastern tip of Flores and in the Solor Archipelago, which covers the islands of Solor, Adonara, and Lembata. These islands are located in the Indonesian province of Nusa Tenggara Timur, which can be seen in Map 1. 


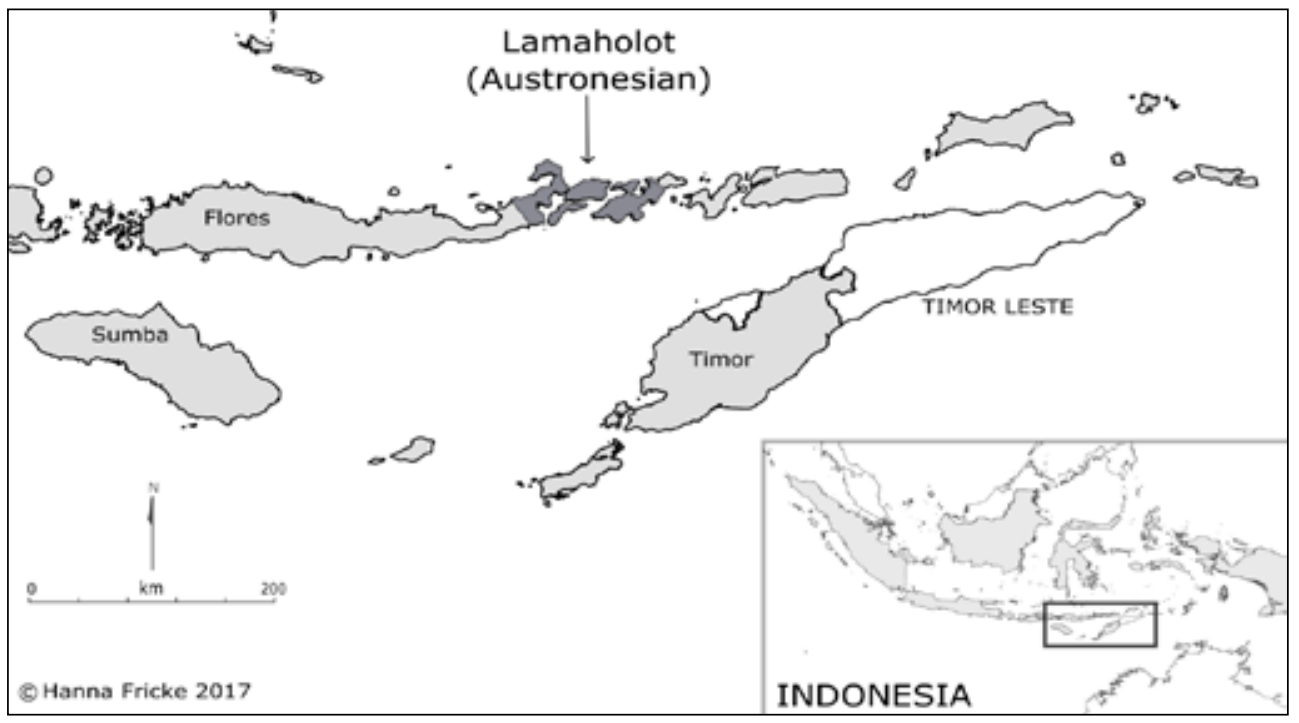

Map 1. Lamaholot in the Indonesian province Nusa Tenggara Timur (NTT).

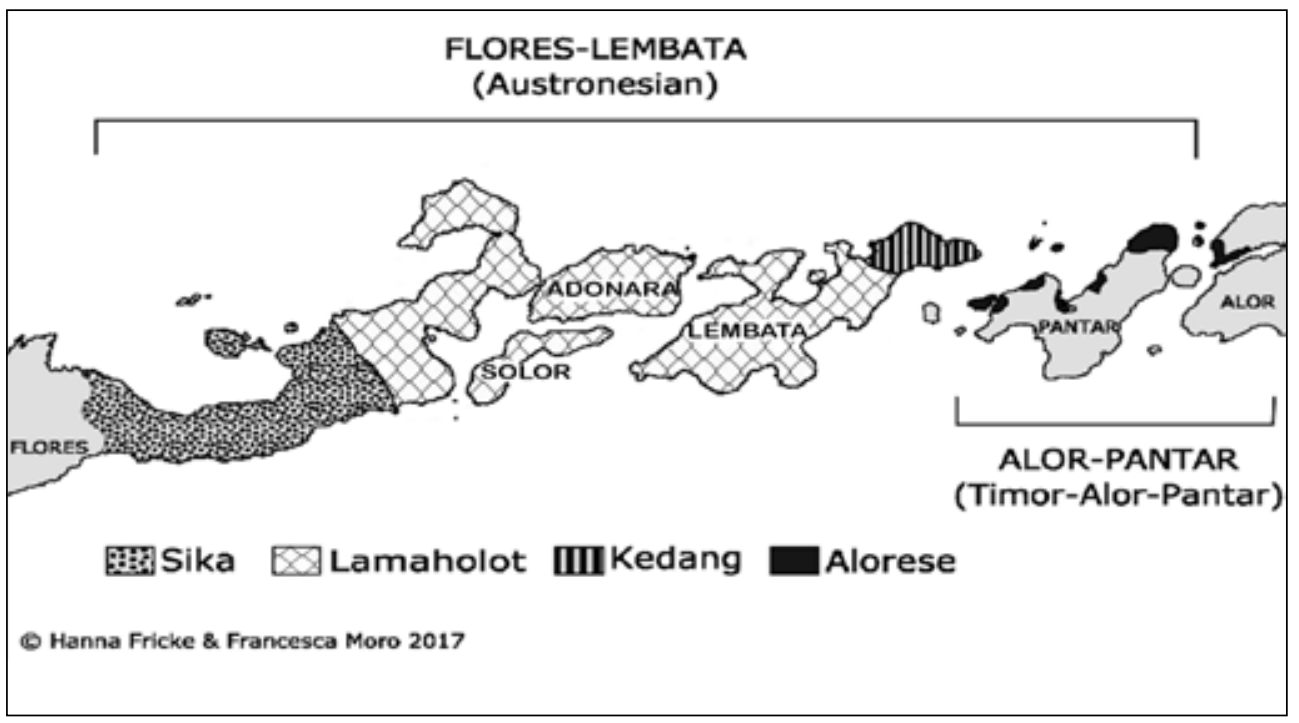

Map 2. The linguistic surroundings of Lamaholot.

Map 2 shows that there are three other Austronesian languages located close to Lamaholot: Sika, Kedang, and Alorese. Together with Lamaholot, they form the group of Flores-Lembata languages. ${ }^{2}$ In addition, there are also non-

2 According to Fernandez (1996), Proto-Flores-Timur (PFT) was the first sub-group which split from Proto-Flores, which is the assumed proto-language of all languages on the island of Flores. However, the languages in Flores are not the only Malayo-Polynesian languages in the area. The Island of Timor (see Map 1) is inhabited by speakers of Malayo-Polynesian and nonAustronesian Timor-Alor-Pantar languages. But the genealogical relation of Lamaholot, Sika, and Kedang to the Malayo-Polynesian languages of Timor has not yet been studied systematically. 
Austronesian languages belonging to the Timor-Alor-Pantar family on the islands of Alor and Pantar (compare Klamer 2014; Schapper 2014).

The description of the neighbouring languages of Lamaholot, Kedang (compare Samely 1991; Samely and Barnes 2013), Sika (compare Arndt 1931; Rosen 1986; Lewis and Grimes 1995; Pareira and Lewis 1998; Fricke 2014), and Alorese (compare Klamer 2011), is still limited compared to that of Lamaholot. No recent full grammar of any of these languages has yet been published.

Alorese is the closest relative of Lamaholot. According to historical and ethnographic sources, speakers of Alorese emigrated from the Lamaholot area to Pantar around the year 1300, and later spread farther to Alor (Klamer 2011: 16). It has been suggested that Alorese is a dialect of Lamaholot (Stokhof 1975: 9) but, on the basis of lexical divergence and morphological simplification compared to Western Lamaholot dialects, Klamer (2011: 24) concludes that Alorese should be considered a separate language.

\section{INTERNAL SUB-GROUPING OF LAMAHOLOT}

Keraf (1978) has compiled the only available dialectological work on Lamaholot. On the basis of lexicostatistics, his work distinguishes three main groups of Lamaholot varieties, which share 55 percent of lexical similarity: Western Lamaholot, Central Lamaholot and Eastern Lamaholot (Keraf 1978: appendix VI). As shown on Map 3, Central and Eastern Lamaholot are found only on the Island of Lembata, whereas Western Lamaholot spread over Eastern Flores, through the islands of Solor and Adonara, to the coastal areas of Lembata.

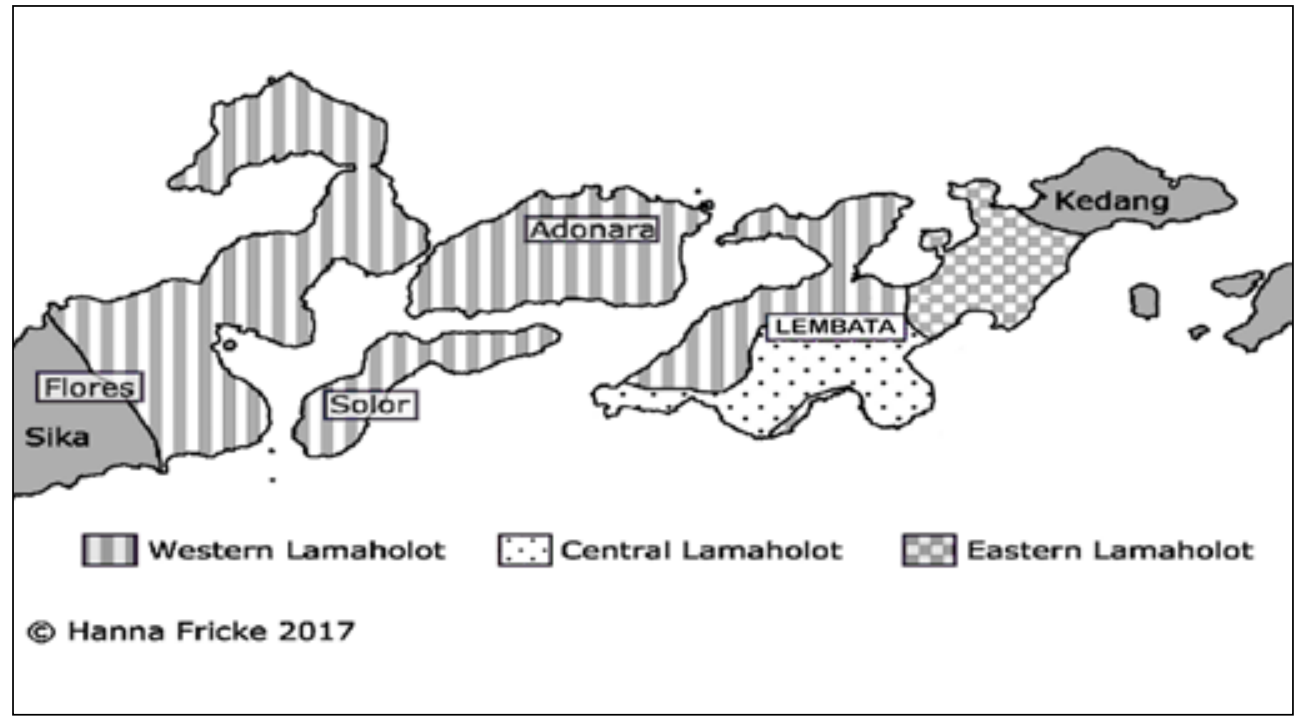

Map 3. Distribution of Lamaholot varieties.

Western Lamaholot represents the biggest group in terms of geographical area and number of speakers. The varieties of Central Lamaholot are found 
in the central and southwestern parts of Lembata, the most isolated areas of the island. Eastern Lamaholot is found in the central-eastern part of Lembata adjacent to Kedang in the east (Keraf 1978: 8-10). Elias (2017) uses Keraf's lexical data to apply the comparative method and Historical Glottometry (François and Kalyan, forthcoming), with the aim of examining the internal sub-grouping of the Lamaholot dialect chain. His findings of regular sound changes confirm Keraf's main groupings into Western, Central, and Eastern Lamaholot, whereby Western and Eastern Lamaholot together form an innovation-defined subgroup as the first split from Proto-Lamaholot.

The linguistic diversity on the Island of Lembata suggests that Lamaholot diversified in the centre and spread from there to more peripheral areas as well as to adjacent islands to the west. Later a group of Western Lamaholot speakers moved towards the east, with one group settling on Pantar and Alor and another group on the south coast of Lembata, in Lamalera. Note that Grangé (2015: 47) has drawn a different conclusion and has suggested that Eastern Adonara as the homeland of Lamaholot. I suggest that Grangé (2015) identified the homeland of Western Lamaholot rather than of the whole Lamaholot chain. This is plausible because not much information was available on Central and Eastern Lamaholot at that point. Grangé (2015: 48) himself suggests that more research on the Lamaholot varieties on Lembata is needed to confirm or reject his hypothesis that Eastern Adonara as the Lamaholot homeland.

\section{PREVIOUS DESCRIPTIVE WORK ON LAMAHOLOT}

The first linguistic description of Lamaholot was published in 1937 by the German missionary Paul Arndt, using information from several western dialects but excluding dialects on Lembata (Arndt 1937: 3). The grammar is written in German and has a structure based on the grammar of a European language. For modern-day use, it is unfortunate that the language examples are not always translated and never glossed on a word-by-word basis. On the other hand, it represents a comparatively early record of the language and in some cases can point to older stages of the language.

In the 1970s, two linguists, native to different parts of the Lamaholot area, published two grammatical descriptions, in Indonesian, of Western Lamaholot varieties. Fernandez (1977) provides a short description of Lamaholot spoken around the mountain Ile Mandiri, close to the city of Larantuka in Flores. Keraf (1978) describes the morphology of the Lamalera dialect, a village on the south coast of Lembata. Although located quite far to the east, this Lamaholot variety is linguistically part of the Western Lamaholot group (Keraf 1978: 10). The exceptional aspect of Keraf's work is his lexical dialect survey, which he includes in the appendix. As mentioned in Section 3, Keraf's dialectological work is the basis for what is known about the internal classification and lexical diversity within Lamaholot.

Contemporary research on Lamaholot has involved linguists of various origins. Nishiyama and Kelen (2007) offer a brief description of the variety 
of the villages Lewoingu and Lewolaga located in the eastern part of Flores. Nagaya (2011) presents a grammar description of one of the westernmost Lamaholot varieties spoken around the mountain Lewotobi located in Flores. Grangé (2015) describes split intransitivity in East Adonara Lamaholot and compares several Lamaholot varieties in terms of their lexicon. Kroon (2016) has compiled a descriptive grammar of the variety of Lamaholot spoken on the Island of Solor.

It is worth noting that all the descriptions published are of varieties of Western Lamaholot (compare classification in Section 3). There are two recent works by Master's students which deal with varieties of Central Lamaholot. Akoli (2010) describes aspects of the Lewokukung variety, using a word list of 200 basic items and a transcribed and translated folk-story. Krauße (2016) provides a brief sketch of the grammar on the variety of Central Lamaholot spoken on the Atadei Peninsula on the south coast of Lembata. My ongoing research and dissertation (Fricke In prep.) will include the first more extensive description of Central Lembata Lamaholot, which is likewise part of the Central Lamaholot sub-group. Eastern Lamaholot remains largely undescribed.

\section{Central Lembata Lamaholot}

\subsection{LOCATION AND LANGUAGE NAME}

Central Lembata is spoken in several villages in the central mountains on the Island of Lembata. This article is based on natural speech data collected in the villages of Kalikasa (Katakeja), Bakan (lle Kerbau), and Lewaji (Dori Pewut) located in the north-western part of the Atadei district, indicated on Map 4. ${ }^{3}$

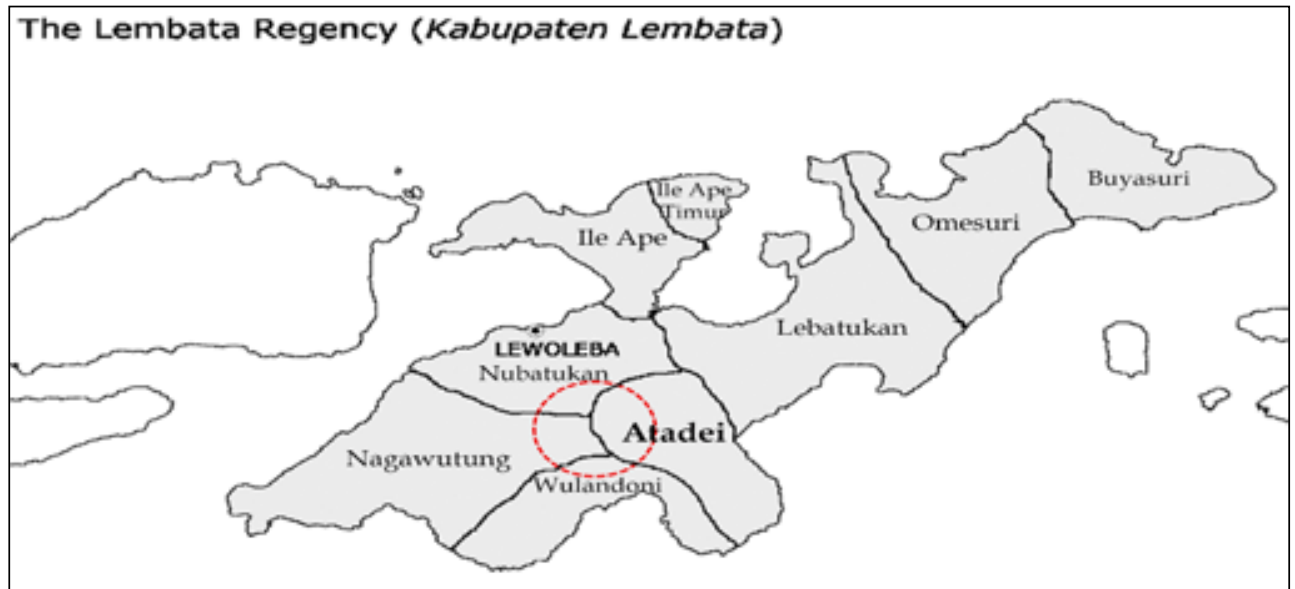

Hanna Fricke 2017

Map 4. The Lembata Regency with districts (kecamatan) boundaries and regency (kabupaten) capital Lewoleba.

3 Especially on Lembata, all villages have a newer, second name, here in brackets, which is used for official purposes. 
Other smaller Central Lembata-speaking villages in this district are Kolilerek (Tubuk Rajan), Waimuda (Nuba Boli), and Mudalerek (Nogo Doni). Examining information from local informants and Keraf (1978), this variety of Lamaholot is also spoken in a few more villages towards the west. ${ }^{4}$ Among those are Boto (Laba Limut) and Udek in the Nagawutung district and Lewuka (Belobao) in the Wulandoni district.

I have chosen the language name Central Lembata as a geographical label to cover the area described above. A new name had to be coined because speakers do not have a name for this language variety and no previous linguistic description of it exists. Notably, speakers of Central Lembata preferred not refer to their language using the term Lamaholot. Most of the time, they would refer to it as bahasa daerah, Indonesian for 'local language', or combine the Indonesian term bahasa 'language' with a village name. For them, Lamaholot is the language used on the islands of Flores, Solor, Adonara, and Ile Ape, a peninsula in the northern part of Lembata, the area which has been classified as Western Lamaholot by Keraf (1978). However, in the literature, the term Lamaholot is used to refer to the whole dialect chain.

\subsection{Nouns in Central Lembata}

Central Lembata distinguishes between three types of nouns: Inalienable, Alienable Type A and Alienable Type B. This distinction is reflected in the semantic and grammatical features of these nouns, summarized in Table 1.

\begin{tabular}{|c|c|c|c|}
\hline & \multirow[t]{2}{*}{ INALIENABLE } & \multicolumn{2}{|c|}{ Alienable } \\
\hline & & Type A $(60 \%)$ & Type B (40 \%) \\
\hline SEMANTIC FIELDS & $\begin{array}{l}\text { body parts } \\
\text { kinship terms } \\
\text { parts of wholes }\end{array}$ & \multicolumn{2}{|c|}{ All others } \\
\hline $\begin{array}{l}\text { FINAL PHONEMES } \\
\text { (TENDENCY) }\end{array}$ & all & $/ \mathrm{V}, \mathrm{n}, \mathrm{y}, \mathrm{d}_{3}, \mathrm{v} /$ & $/ \mathrm{p}, \mathrm{t}, \mathrm{k}, \mathrm{s}, \mathrm{m}, \mathrm{r}, \mathrm{l} /$ \\
\hline $\begin{array}{l}\text { FINAL CODA } \\
\text { ALTERNATION }\end{array}$ & no alternation & $\begin{array}{l}\text { alternation } \\
\text { between presence } \\
\text { and absence of } \\
\text { final coda }\end{array}$ & no alternation \\
\hline SUFFIX SLOT & Possessor suffix & \multicolumn{2}{|c|}{$\begin{array}{c}\text { Specificity suffix } \\
\text { Plural suffix }\end{array}$} \\
\hline
\end{tabular}

Table1. Noun types in Central Lembata with their semantic and grammatical features.

In semantic terms, inalienable nouns refer to entities which are inalienably connected to another entity. These are referents which logically do not exist without another entity by which they are possessed or of which they are part. 
Under normal circumstances, the two entities cannot be separated. Nouns in this category are typically body-part nouns, kinship terms and parts of wholes. On the other hand, most of the alienable nouns can also be possessed but, if they are, this connection can be dissolved. The vast majority of Central Lembata nouns are either inalienable or alienable. However, there are a few exceptions in which a noun can behave as inalienable or alienable depending on the context in which it occurs. An example is knawi 'door'. This word can be either seen as an independent entity, in which case it will behave as alienable, or as a part of the whole, namely of a house or hut, in which case it will behave inalienably.

Inalienable nouns can terminate in any consonant or vowel that is allowed word finally. For alienable nouns, the underlying final phoneme determines the sub-type, Type A or Type B. ${ }^{5}$ Alienable Type A nouns terminate underlyingly in $/ V, n, y, d 3, v /$, whereas Alienable Type $B$ nouns terminate in any other consonant. Note that this distribution is a tendency, therefore a few exceptions do exist (see Section 5.2.1 for further discussion).

The semantic distinction between inalienable and alienable nouns is grammaticalized in Central Lembata Lamaholot. Two main nominal features are affected by this distinction: 1) the presence of final coda alternation, and 2 ) the type of suffixes available to the noun. Final coda alternation is the cooccurrence of two realizations of the same lexeme, one having a final coda and the other being coda-less. Inalienable nouns never show final coda alternation, whereas alienable nouns exhibit this phenomenon in around 60 percent of the nouns of this class, depending on their underlying final phoneme. All nouns in Central Lembata have only one slot for suffixes available. The set of affixes which can be used in this slot is complementary for inalienable and alienable nouns. Inalienable nouns obligatorily take possessor suffixes, whereas alienable nouns can take a specific suffix, a plural suffix or no suffix.

In the following, I first discuss alienable nouns, with a focus on final coda alternation for Alienable Type A nouns, and then suffixes for all three noun types.

\subsubsection{Alienable NOUNS AND FinAl CODA ALTERNATION}

Only Alienable Type A nouns have final coda alternation, which means that these nouns possess two forms which are distributed according to their position in the clause. I shall return to the distribution patterns after I have introduced the formal aspects of this noun type. Table 2 lists a number of examples of alienable nouns of Type A with final coda alternation and Type $B$ with just one stable form. 


\begin{tabular}{|l|l|l|l|}
\hline \multicolumn{2}{|l|}{ Type A (60\%) } & \multicolumn{2}{l|}{ Type B (40\%) } \\
\hline $\begin{array}{l}\text { au } \\
\text { aor }\end{array}$ & 'dog' & manuk & 'chicken' \\
\hline $\begin{array}{l}\text { viti } \\
\text { viter }\end{array}$ & 'goat' & kebol & 'sugar palm' \\
\hline $\begin{array}{l}\text { liso } \\
\text { lisor }\end{array}$ & 'rice plant' & taum & 'indigo plant' \\
\hline $\begin{array}{l}\text { kopo } \\
\text { kopoy }\end{array}$ & 'child' & garop & 'young woman' \\
\hline $\begin{array}{l}\text { eke } \\
\text { eken }\end{array}$ & 'bamboo stairs' & apur & 'lime' \\
\hline $\begin{array}{l}\text { una } \\
\text { unan }\end{array}$ & 'house' & omut & 'dust' \\
\hline $\begin{array}{l}\text { kara } \\
\text { karadz }\end{array}$ & 'grain' & snae & 'shawl' \\
\hline
\end{tabular}

Table 2. Alienable nouns in Central Lembata.

Coda alternating nouns have two realizations of the same lexeme. Table 2 shows that one of the forms is consonant-final and the other one is vowel-final. Type B nouns are mainly consonant-final. As shown in Table 1, the distribution of alienable nouns over Type A, with coda alternation, and Type B, without it, is phonologically conditioned. In most cases, the existence or absence of coda alternation, hence the classification into Type A or B, can be predicted by the underlying final phoneme of the noun.

\begin{tabular}{|ll|l|l|}
\hline $\begin{array}{l}\text { Underlying final phoneme } \\
\text { and type frequency }\end{array}$ & Form & GLOss \\
\hline $\mathrm{k} \quad(\mathrm{B}: 36-\mathrm{A}: 3)$ & ulik & 'bed; bamboo platform' \\
\hline $\mathrm{t}$ & $(\mathrm{B}: 20-\mathrm{A}: 1)$ & morit & 'knife' \\
\hline $\mathrm{r}$ & $(\mathrm{B}: 17-\mathrm{A}: 2)$ & kunur & 'breadfruit' \\
\hline $\mathrm{l}$ & $(\mathrm{B}: 15-\mathrm{A}: 1)$ & kadal & 'fence' \\
\hline $\mathrm{m}$ & $(\mathrm{B}: 10-\mathrm{A}: 1)$ & padzam & 'papaya' \\
\hline $\mathrm{p}$ & $(\mathrm{B}: 4-\mathrm{A}: 0)$ & bapap & 'monitor lizard' \\
\hline $\mathrm{s}$ & $(\mathrm{B}: 4-\mathrm{A}: 0)$ & tomus & 'whale' \\
\hline
\end{tabular}

Table 3. Underlying final phonemes which mainly yield Type B nouns without final coda alternation.

I commence the discussion with the phonemes which yield Type B nouns because they are simpler, having only one stable lexeme realization. These phonemes are listed in Table 3, exemplified by one example each. In brackets, I provide numbers of noun occurrences in my corpus for each final phoneme. I 
also give numbers of exceptional cases, where nouns with these final phonemes unexpectedly pattern with Type A and therefore have two forms.

Table 4 shows the underlying final phonemes which yield final coda alternation, namely: Type A nouns. In line with the Table 3, for each final phoneme, the number of occurrences in my corpus is given in brackets, as well as the number of exception cases, where nouns with these final phonemes unexpectedly pattern with Type B. In Table 4, I also provide the underlying form, as well as the two realizations of the lexeme.

\begin{tabular}{|ll|l|l|l|l|}
\hline $\begin{array}{l}\text { Underlying final } \\
\text { phoneme and type } \\
\text { frequency }\end{array}$ & $\begin{array}{l}\text { UNDERLYING } \\
\text { FORM }\end{array}$ & $\begin{array}{l}\text { V-FINAL } \\
\text { FORM }\end{array}$ & $\begin{array}{l}\text { C-FINAL } \\
\text { FORM }\end{array}$ & GLOSS \\
\hline $\mathrm{V} \quad(\mathrm{A}: 99-\mathrm{B}: 12)$ & au & au & aor & 'dog' \\
\hline $\mathrm{n}$ & $(\mathrm{A}: 47-\mathrm{B}: 4)$ & pirin & piri & pirin & 'plate' \\
\hline $\mathrm{n} \quad(\mathrm{A}: 26-\mathrm{B}: 1)$ & ikan & $i k a$ & ikan & 'fish' \\
\hline $\mathrm{d} 3 \quad(\mathrm{~A}: 4-\mathrm{B}: 3)$ & uad3 & ua & uad3 & 'rattan' \\
\hline $\mathrm{V}$ & $(\mathrm{A}: 1-\mathrm{B}: 0)$ & ktumav & ktuma & ktumav & 'louse on clothing' \\
\hline
\end{tabular}

Table 4. Underlying final phonemes which mainly yield Type A nouns with final coda alternation.

From Table 4, it can be seen that alienable nouns which underlyingly end in a vowel or in $/ \mathrm{y}, \mathrm{n}, \mathrm{d} 3, \mathrm{v} / \mathrm{have}$ alternating forms. Note that the case of final $/ d_{3} /$ is problematic as the number of cases in which this final phoneme yields Type B, three times in the corpus, is almost as high as the number of cases in which it yields Type A, four times. To derive the second form from the underlying form, vowel-final nouns add the consonant/r/ as in au/aor ' $\mathrm{dog}^{\prime}$, while nouns underlyingly ending in a consonant, drop this final consonant as in piri/piriy 'plate'. When final / $\mathrm{r} /$ is added to a vowel-final noun, final high vowels $/ \mathrm{i}, \mathrm{u} /$ are lowered to mid vowels $/ \mathrm{e}, \mathrm{o} /$. This can be seen in the example of $a u$ 'dog' where $/ \mathrm{u} /$ is lowered to $/ \mathrm{o} /$ when $/ \mathrm{r} /$ is added to derive the alternating form aor. The origin of the added phoneme $/ \mathrm{r} /$ remains unknown. In the example piriy 'plate', the final consonant is dropped to gain the alternating form piri. Dropping the final consonant does not cause any phonological changes on the noun.

The criterion for determining the underlying form is the predictability of the derived form. For the pair of $a u / a o r$ ' $\mathrm{dog}^{\prime}$, the vowel-final form is the underlying form because, from the consonant-final form, it was impossible to predict whether the final vowel would be $/ \mathrm{o} /$ or $/ \mathrm{u} /$. In the same way, pirin 'plate' has to be underlying because from piri 'plate', the final consonant $/ \mathrm{y} /$ could not be predicted. In fact, the underlying form usually matches the etymology of the noun. As with these examples, au/aor 'dog' comes from PMP *asu 'dog' (Blust and Trussel 2010) and piri/piriy is borrowed from Malay piri 'plate'. 
The two shapes of a Type A noun are used in different contexts. The constraints listed in (1) apply to their distribution.

(1) Distribution constraints of the two shapes of Alienable Type A nouns

- Morpho-phonological constraint: When the noun takes a suffix, the form with a coda has to be used.

- Syntactic constraints:

a. If the noun is located within a verb phrase (VP) the coda-less form has to be used.

b. If the noun is a non-final element within a noun phrase (NP), the coda-less form has to be used.

In the following examples, each of these distribution rules is exemplified using the noun kopo / kopoy 'child'.

Following the morpho-phonological constraint, Type A nouns have to be realized in their consonant-final form when the plural suffix $-d_{3} a(2)$ or the specificity suffix $-r u$ (3) is added. In these examples the underlying clusters $/ \mathrm{nd} 3 /$ and $/ \mathrm{nr} /$ are resolved by deleting the second consonant.

(2) kopona

kopon-dza

child-pL

'children.'

(3) koponu

kopon-ru

child-SPEC

'the child.'

Consonant clusters are resolved according to morpho-phonological processes, which are discussed in more detail in the Section 5.2.2 nominal suffixes.

Following the first syntactic constraint, the coda-less form is used when the noun is located within a verb phrase. This means that nominal objects following the verb always appear in the coda-less form as shown in example (4), with the noun kopo/kopoy.

$\begin{array}{lll}\text { (4) Kam } & \text { [paraw } & \text { kopo]vp } \\ \text { 1PL.EXCL } & \text { feed } & \text { child }\end{array}$

'We bring up (our) children.' 
Following the second syntactic constraint, non-final nouns in a noun phrase take the coda-less form. Therefore, a noun which is followed by either another noun, an adjective, a numeral (+classifier), or a combination of these, takes the coda-less form. In Central Lembata, modifiers generally follow the noun. This is illustrated by the noun phrase in example (5). Note that demonstratives are not part of the NP in Central Lembata.

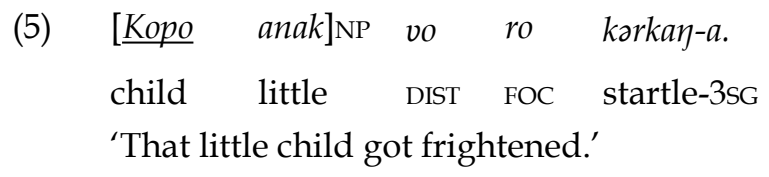

In all other cases, where the noun is neither part of a VP nor is it accompanied by another element within the NP, the consonant-final form is used. This is the case, for instance, (6), where the noun represents the only element in a subject NP.

$\begin{array}{llll}\text { (6) } \quad[\underline{\text { Kopon }}] \mathrm{NP} & \text { ksopel } & \text { dze } & \text { lodo. } \\ \text { child } & \text { jump } & \text { uP } & \text { descend }\end{array}$

'The child jumps down.'

As expected, according to the criteria given above, the citation form of a noun and a fronted object take the consonant-final form, as long as they are not accompanied by any other element in the NP.

\subsubsection{NOMINAL SUFFIXES}

All nouns in Central Lembata have only one slot available for suffixes. Inalienable nouns take a possessor suffix in this slot, whereas alienable nouns have either no suffix, a plural suffix or a specificity suffix.

\begin{tabular}{|l|l|}
\hline & POSSESOR SUFFIX \\
\hline 1SG.POSS & $-g a$ \\
\hline 2sG.POSS & $-m u$ \\
\hline 3sG.POSS & $-n u /-: /-\varnothing$ \\
\hline 1PL.INCL & $-s a$ \\
\hline 1PL.EXCL & $-m i$ \\
\hline 2PL.POSS & $-m i$ \\
\hline 3PL.POSS & $-i\left(-d_{3} a\right)$ \\
\hline
\end{tabular}

Table 5. Possessor suffixes.

In Table 5, I give the paradigm of possessor suffixes for inalienable nouns. The 3PL.Poss form $-d_{3} a$ is used for vowel-final stems, whereas $-i$ attaches to consonant-final stems. The three variants for 3sG.POSs show an unclear pattern 
which cannot yet be fully explained. However, there appears to be a tendency for $-n u$ to be used with kinship terms and for vowel lengthening and zero to alter with vowel-final and consonant-final body part terms respectively.

The use of a possessor suffix is illustrated with the inalienable nouns lotor 'knee', lima 'hand', and ina 'mother' in (7). Note that, in addition to the obligatory possessor suffix, a free realis pronoun indicating the possessor can be added optionally to the possessed noun (compare Section 5.3).

(7) Inalienably possessed nouns

$\begin{array}{llll} & \text { 'knee' } & \text { 'hand' } & \text { 'mother' } \\ \text { 1sG.POSS } & \text { lotor-ga } & \text { lima-ga } & \text { ina-ga } \\ \text { 2sG.POSS } & \text { lotor-mu } & \text { lima-mu } & \text { ina-mu } \\ \text { 3sG.POSS } & \text { lotor- } \varnothing & \text { lima-: } & \text { ina-nu } \\ \text { 1PL.INCL } & \text { lotor-mi } & \text { lima-sa } & \text { ina-sa } \\ \text { 1PL.EXCL } & \text { lotor-mi } & \text { lima-mi } & \text { ina-mi } \\ \text { 2PL.POSS } & \text { lotor-mi } & \text { lima-mi } & \text { ina-mi } \\ \text { 3PL.POSS } & \text { lotor-i } i & \text { lima-dza } & \text { ina-dza }\end{array}$

Alienable nouns cannot take a possessor suffix. To form a possessive construction, a free possessor pronoun goe is placed before the noun, as in (8).

goe unan
1sG.POss house
'my house'

Alienable nouns of both types, Type A and Type B, use the suffix slot to express plural number or specificity. For plurality marking, the plural suffix $-d z a$ is employed as in (9) and for specificity marking the specific suffix - $r u$ as in (10).

(9)
snae- $\underline{d z a}$
shawl-PL
'shawls'
shawl-SPEC
'the shawl'

(10) snae- $\underline{r u}$

The plural suffix is only used when no other indication of plurality, a numeral or quantifier, occurs in the noun phrase. It can be used for all kinds of alienable nouns, including animates and inanimates, with the exception of specific concepts which inherently cannot have a plural meaning, such as 'sky' or 'sun'. Note that the 3PL.POss form - $d 3 a$ (compare Table 5) is a likely source for 
the plural suffix used on alienable nouns. The development of a 3PL pronoun into a plurality marker is a very common pathway of grammaticalization found in Austronesian languages and languages around the world (Holm 2000: 215-217; Michaelis 2008: 205; Wu 2017: 61). Inalienable nouns cannot express plural numbers on the nouns themselves as their suffix slot is already occupied by the obligatory possessor suffix. A plural number of a body-part term can only be expressed explicitly in a sentence, as in (11), where the plurality of the noun lotor is encoded in the verb agreement.

$$
\begin{aligned}
& \text { Lotor-ga di } \quad \text { gesol-i. } \\
& \text { knee-1sG.Poss also } \quad \text { sprain-3PL } \\
& \text { 'My knees are also sprained.' }
\end{aligned}
$$

As already mentioned in Section 5.2.1, morpho-phonological rules apply when consonant-final alienable nouns take a plural or specificity suffix. The same rules apply to all alienable nouns which take a suffix regardless of whether they belong to Type A or B. For Type A nouns, a suffix always has to be attached to the consonant-final form. Therefore, the only case in which a suffix is attached to a vowel-final noun is a Type B noun that is vowel-final, as in examples (9) and (10). Depending on the nature of the consonants involved, either the coda consonant or the initial consonant of the suffix is deleted. The rules listed in (12) apply.

(12) Morpho-phonological rules

1. Rule for attaching the specificity suffix $-r u$ $\mathrm{r} \rightarrow$ zero /[C]_u\#\#

$\begin{array}{lllll}\text { kopon } & +\underline{r} u & \rightarrow & \text { kopon } u & \text { 'child-SPEC' } \\ \text { manuk } \underline{r}+\underline{r} u & \rightarrow & \text { manu } \underline{k} u & \text { 'chicken- SPEC' }\end{array}$

2. Rules for attaching the plural suffix $-d_{3} a$

a. $\quad[\mathrm{n}, \mathrm{r}] \rightarrow$ zero / _-dza\#\#

\begin{tabular}{|c|c|c|c|c|}
\hline kopon & $+\quad \underline{d z} a$ & $\rightarrow$ & kopona & 'child-PL' \\
\hline kadal & $\underline{d z} a$ & $\rightarrow$ & kadala & 'fence-PL' \\
\hline \multicolumn{5}{|c|}{$[p, t, k] \rightarrow s /$ a\#\#\# } \\
\hline manuk & $+\quad \underline{d z} a$ & $\rightarrow$ & manus $a$ & 'chicken-PL' \\
\hline ramut & $d_{3} a$ & $\rightarrow$ & ramus $a$ & 'root-PL' \\
\hline
\end{tabular}

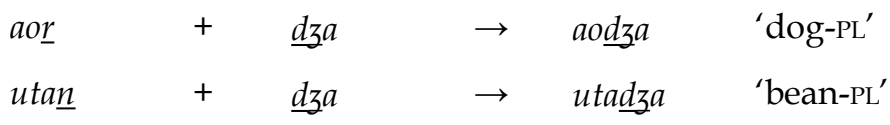

b. $\quad \mathrm{d}_{3} \rightarrow$ zero / [dz, m, n, l, v, s, p, t, k]-_a\#\# 
Following Rule 1, the initial / $\mathrm{r}$ / of the specificity suffix $-r u$ is only realized when the noun is vowel-final. In all other cases, the $/ \mathrm{r} /$ is dropped. The initial / d $3 /$ of the plural suffix $-d_{3} a$ is likewise realized when it is attached to a vowel-final noun. However, with consonant-final nouns, the realization of the suffix depends on the quality of the final consonant. Following rule $2 \mathrm{a}$, $/ d_{3} /$ is realized when the final consonant of the noun is either $/ \mathrm{n} /$ or $/ \mathrm{r} /$. These final consonants are dropped and / $d_{3} /$ remains. Following rule $2 b$, other final consonants are retained but they cause the initial /d3/ of the suffix to be dropped. Additionally, rule 2c, which transforms voiceless stops into fricatives before the suffix, applies. ${ }^{6}$

The liquids $/ 1 /$ and $/ \mathrm{r} /$ do not always behave according to the general rules. The final consonant $/ 1 /$ normally follows rule $2 b$, thereby causing the deletion of $/ d_{3} /$ in the suffix (13 occurrences in the corpus). However, three $/ 1 /$-final nouns follow rule $2 a$, which means that $/ 1 /$ is deleted and the initial /d3/ is kept. The final consonant / $r$ / usually follows rule $2 a$ (116 occurrences in the corpus). However, in 12 cases the final consonant $/ r /$ follows rule $2 b$ and is retained.

\subsection{Person marking in Central Lembata}

Central Lembata has a comparably rich inventory of free and bound person marking pronouns. Furthermore, there is an association of person marking with mood and aspect as one set of the free subject pronouns is only used in irrealis contexts and the person suffixes can be used to express completive aspect and imperative mood. In the following section, I first present the free pronouns, and then I discuss pronominal affixes in Central Lembata.

\subsubsection{FREE PRONOUNS}

In Table 6, I present the free pronoun sets of Central Lembata. These include a full set of disyllabic pronouns, two incomplete sets of monosyllabic reduced forms and a full set of monosyllabic irrealis pronouns, of which three are identical to the short realis form for 3sG, 1.PL.INCL and 3PL.

The whole set of full pronouns given in Table 6 can appear as S, A, and $P$ arguments, therefore in both subject and object positions. ${ }^{7}$ The use of short forms, however, is more restricted. Only the 1sG and 2sG short forms can be used in all argument slots. The other short forms, namely 3sG, 1PL.INCL and $3 \mathrm{PL}$, can only be used as subject arguments. Apart from the full and short forms of realis pronouns, there is a full set of irrealis pronouns which can only appear in subject position. Irrealis mood, in contrast to realis mood, is used to express that there is no evidence for an event or state having actually happened (compare Payne 1997: 244). For example, in Central Lembata, an irrealis pronoun appears where the speaker expresses the intention to do

\footnotetext{
6 Historically, this change could also have been $/ \mathrm{d}_{3} / \rightarrow / \mathrm{s} /$ while dropping the consonants $/ \mathrm{p}, \mathrm{t}, \mathrm{k} /$.

$7 \mathrm{~S}=$ subject of an intransitive verb; $\mathrm{A}=$ subject of $\mathrm{a}$ transitive verb; $\mathrm{P}=$ object of a transitive verb.
} 
something, as in (13) and (14).

\begin{tabular}{|l|l|l|l|l|}
\hline \multirow{2}{*}{} & \multicolumn{3}{|c|}{ REALIS } & \multirow{2}{*}{ IRREALIS } \\
\cline { 2 - 5 } & \multicolumn{2}{|c|}{ SAP } & \multirow{2}{*}{ SA } \\
\cline { 2 - 5 } & LONG & \multicolumn{2}{|c|}{ SHORT } & \\
\hline 1SG & gone & go & - & $\mathrm{ka}$ \\
\hline 2SG & mone & mo & - & $\mathrm{ma}$ \\
\hline 3SG & nane & - & $\mathrm{na}$ & $\mathrm{na}$ \\
\hline 1PL.INCL & tite & - & - & $\mathrm{ta}$ \\
\hline 1PL.EXCL & kame & - & $\mathrm{kam}$ & $\mathrm{kam}$ \\
\hline 2PL & mio & - & - & $\mathrm{ma}$ \\
\hline 3PL & dane & - & $\mathrm{da}$ & $\mathrm{da}$ \\
\hline
\end{tabular}

Table 6. Free person pronouns.

(13) $\mathrm{Ma} \underline{\mathrm{ka}}$ tutu tentay Dzon no Meri.

want 1sG.IRR tell about John and Mary

'I want to tell about John and Mary.'

(14) Sampe mingu dzua kia, nәро $\underline{k a}$ k-ai dur-a eka.

until week two first then 1SG.IRR 1sG-go look-3sg garden

'Only in two weeks from now, shall I go to look after the garden.'

Irrealis pronouns are also used in negative sentences, as in (15) and imperatives, as in (16).

$\begin{array}{llll}\operatorname{Ta} \quad \underline{k a} & k \text {-etan-a } & \text { si. } \\ \text { NEG } & \text { 1sG.IRR } & \text { 1sG-know-3sG } & \text { NEG } \\ \text { 'I don't know'. } & \end{array}$

(16) $\underline{M a}$

gute- $\varnothing$, ve ka lou-ni.

2SG.IRR take-3PL so.that 1SG.IRR rinse-3PL

'Take them [washed clothes], so that I can rinse them.'

Example (17) shows that an irrealis pronoun cannot be combined with the perfective aspect marker kei.

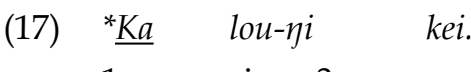

1SG.IRR rinse-3PL PRF

Intended: 'I already rinsed them.' 
To express the intended meaning 'I already rinsed them', a realis pronoun has to be used, as in (18).

$\begin{array}{lll}\text { (18) } & \frac{\text { Go }}{\text { 1sG }} \quad \begin{array}{ll}\text { rou- } \eta i & \text { kei. } \\ \text { rinse-3PL } & \text { PRF }\end{array} \\ \text { 'I already rinsed them.' }\end{array}$

The irrealis pronoun can only appear without kei, as in (19), which yields the meaning 'I shall rinse them' or 'I can rinse them'.

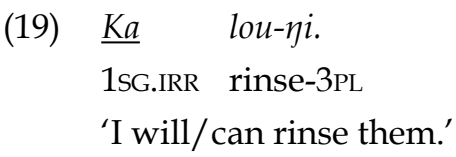

\subsubsection{BOUND PRONOUNS}

Having shown the different types of free pronouns, I now turn to pronominal affixes. There is one set of pronominal prefixes and two sets of pronominal suffixes, all given in Table 7. The forms given in brackets are used for verbal stems that end in a vowel.

\begin{tabular}{|l|l|l|l|}
\hline \multirow{2}{*}{} & \multirow{2}{*}{ SA } & \multicolumn{2}{c|}{ SP } \\
\cline { 3 - 4 } & & \multicolumn{1}{c|}{ SET 1 } & \multicolumn{1}{c|}{ SET 2 } \\
\hline 1SG & $k-$ & $-g a$ & $-k a$ \\
\hline 2SG & $m-$ & $-u(-g u)$ & $-k u$ \\
\hline 3SG & $n-$ & $-a(-\eta u)$ & $-n a$ \\
\hline 1PL.INCL & $t-$ & $-s a$ & $-s a$ \\
\hline 1PL.EXCL & $m-$ & $-m i$ & $-m i$ \\
\hline 2PL & $m-$ & $-m i$ & $-m$ \\
\hline 3PL & $d-$ & $-i(-\eta i)$ & $-\varnothing$ \\
\hline
\end{tabular}

Table 7. Bound personal pronouns.

The personal prefixes obligatorily mark subject arguments, either subject of intransitive verbs (S) or subject of transitive verbs (A). The set of prefixes in Table 7 is only used for a specific sub-set of vowel-initial words, mainly verbs but also a few functional words. Most vowel-initial verbs in Central Lembata do not take a prefix. The set of roots with an obligatory person prefix is listed in (20).

(20) Roots with an obligatory S/A person prefix

$-a$ (reduplicated) 'unintentionally', -ai 'go', -ar ' $\mathrm{do}^{\prime}$, -ata 'the one that ...',-enu 'drink', -əra 'become; use; wear', -etən 'know; understand', -əti 
'bring', -əva 'catch; reach', -ia 'stay', -o 'to', -olu 'precede', -ora 'join; be with'.

In addition to the prefixes, Table 7 lists two sets of suffixes. The personal suffixes are formally and functionally more complicated than the prefixes. There are two formal sets of suffixes whose functions include the person indexing on the verb, completive aspect and imperative mood. Concerning personal marking, both sets of suffixes can be used to mark either the subject of intransitive verbs $(\mathrm{S})$ or the object of transitive verbs $(\mathrm{P})$. The choice of the suffix set is determined by the verbal lexeme. Examples (21) and (22) illustrate the indexing of the subject on an intransitive verb (S). In (21), the intransitive verb sgelat 'slip' takes - ga '1 $1 \mathrm{sG}^{\prime}$ from Set 1 to index the 1sG subject argument and in (22) the intransitive verb toba 'fall' indexes the 1sG subject argument using $-k a$ ' $1 \mathrm{sG}^{\prime}$ from Set 2.
(21) Go sgelat-ga.
1sG slip-1sG
'I slipped.'
(22) ...ke toba-ka. thus fall-1sG
'... so, I fell down.'

The same suffixes which are used to mark $S$ in examples (21) and (22) are used to index the transitive object (P) argument in (23) and (24) respectively.
(23) Na gavak-ga ...
3sG hug-1sG
'She hugged me.'
(24) Ma belo-ka.
2sG.IRR cut-1sG
'You will kill me.'

From the examples given above, it becomes clear that both suffix sets appear with the same argument indexing function. Set 2 is clearly a minor pattern, only appearing on around 30 verbs in my corpus, whereas 218 verbs take suffixes of Set 1 . In (25), I list the verbs which take Set 2 . Note that bound verbal roots that take an obligatory personal prefix can also fall into this set. Bound roots are represented with an initial dash. 
(25) Verbs that take Set 2 suffixes

badzu 'to pound', bari 'to pick', batu 'to throw', biti 'to execute a certain weaving process', boti 'to carry; to hold', bura 'to be full (of food)', diri 'to stand', -ati 'to bring', gale 'to lie down; to sleep', gato 'to be broken', gava 'to be rotten', gevi 'to ascend; to enter', giki 'to bite', gliku 'to hold; to place a holder', guti 'to take', ire 'to visit; to play; to walk about', kari 'to run', labo 'to take a shower; to take a bath', livu 'to fill in', mea 'to be on one's own', modo 'to fall', nabu 'to not be thirsty', nubu 'to grow', rio 'to wake someone up', sodi 'to catch', tota 'to burn down', tuno 'to grill', vara 'to burn', vidu 'to pull'.

It is possible that the minor pattern is an older pattern, which might have been retained because the verbs are very frequently used. Another hint of it being old is the presence of the phoneme / $\mathrm{k} /$ in the 1 sG and 2sG. This phoneme is historically associated with 1SG and 2sG pronouns, as in Proto-Austronesian (PAN) * $a k u$ ' $1 \mathrm{sG}^{\prime}$ and Proto-Malayo-Polynesian (PMP) *kahu '2sG' (Blust and Trussel 2010), whereas /g/ is only found synchronically in the Lamaholot 1SG pronoun gone.

It should be noted that around thirty intransitive verbs in my corpus cannot take any personal suffixes, such as gulur'snore' in (26). Among others, the following verbs also fall into this category: tukar 'to climb', bovo 'to bark', peyos 'to turn away', and geka 'to laugh'.

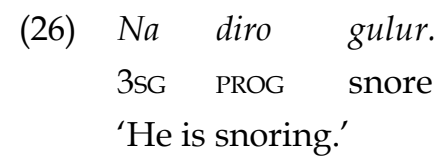

In this case, the subject $S$ is marked the same as $A$. This pattern suggests a split-S alignment system, where $S$ is in some cases marked in the same way as $\mathrm{A}$, namely without a suffix, and sometimes in the same way as $\mathrm{P}$, namely with a suffix.

However, for those verbs which can mark $S$ the same as $P$, using one of the suffix sets, the use of the personal suffix is only obligatory to express completive aspect or imperative mood. The use of a suffix to express completive aspect is illustrated in examples (27) and (28). These two sentences are differentiated only by the presence or absence of the personal suffix -na '3sG' on the verb. The use of the personal suffix -na '3sG' in (27) yields a completive interpretation of the clause, whereby the person has completed the process of climbing onto the stone. Without the suffix, as in (28), the sentence means that the person is in the process of climbing up. 
(27)

$\begin{array}{lllll}\mathrm{Na} & \text { geve-na } & \text { la } & \text { vatu } & \text { Lolo } \\ \text { 3sG rise-3sG } & \text { LOC stone top }\end{array}$

'He has climbed on top of the stone.'

(28) $\mathrm{Na}$ gevi la vatu lolo.

3SG rise LOC stone top

'He is climbing onto the stone.'

A further, obligatory use of the personal suffix is found in imperative sentences, as in (29). Without the suffix, the sentence would be declarative, as shown in (30).

\begin{tabular}{|c|c|c|c|c|c|c|}
\hline Mo & bote- $\underline{n a}$ & kopo & vo & nau, & ve & go \\
\hline $2 S G$ & carry-3sG & child & DIST & descend & so.that & $1 \mathrm{sg}$ \\
\hline
\end{tabular}
(30) Mo boti kopo vo nau.
2sG carry child DIST descend
'You are carrying the child down here.'

It remains to be investigated whether, in addition to the aspectual functions of the suffixes, volition and control of the subject referent could play a role in the use of person suffixes, in a similar way as Grangé (2015: 43) describes for Eastern Adonara Lamaholot.

\section{DisCUSSION}

Central Lembata exhibits several unique features in the nominal and pronominal domains. The language grammaticalizes the distinction between inalienable and alienable nouns, whereby inalienable nouns obligatorily mark a possessor using a suffix, while alienable nouns can mark specificity or plurality by means of a suffix on the noun. However, the alienable nouns which underlyingly end in a vowel or in / n, n, $d_{3}, v /$ show final coda alternation, which results in two functionally different forms of the same lexeme, formally differentiated by the presence or absence of a coda. Furthermore, free and bound pronouns in Central Lembata are intertwined with aspect and mood marking. There is a set of free pronouns used only in irrealis contexts and two sets of bound pronouns that can be used to mark completive aspect or imperative mood. Moreover, the alignment system of Central Lembata has elements of Split-S but remains to be further investigated.

When comparing Central Lembata nouns and pronouns to their

8 Note, that the adding of the suffix -na '3sG' causes a vowel lowering of final /i/ in gevi 'rise' to /e/ in geve-na 'rise-3sG'. This leads to the option of leaving out the suffix, keeping the lower vowel and thus, keeping the completive reading. 
equivalents in related or geographically close languages, different patterns emerge. The Central Lembata nominal system appears to be unique to this variety of Lamaholot, whereas several elements in the pronominal system are also found in related varieties and languages. ${ }^{9}$

Final coda alternation of nouns is absent in all other Flores-Lembata languages. However, when taking a wider perspective on languages outside of the Flores-Lembata group, similar alternating systems can be found. Edwards (2016: 15-78) describes synchronic metathesis in Austronesian and nonAustronesian languages of the greater Timor region. Synchronic metathesis is a process in which the order of a final CV or VC sequence is reversed in certain environments. Also in the wider Indonesian area, a similar case has been reported. Ernanda (2017) describes phrasal alternation in Kerinci, an Austronesian language in Sumatra. Kerinci has two forms of each lexeme, which differ in the final syllable of the word and are distributed according to their position in the phrase. Similar to Central Lembata, in both instances there are two alternating lexeme forms which differ in the last syllable of the word and these forms are functionally complementary. While an in-depth comparison of these systems is still to be conducted, a tendency for marking modified words by one of the two forms can be observed (see example (5) in Section 5.2.1). However, each language has further additional rules which apply, and the word classes which are involved in these systems also differ from language to language.

Possessor suffixes are clearly a feature of Lamaholot as a whole, although in other Lamaholot varieties the restriction for possessor suffixes to inalienable nouns is less clear-cut (compare Nishiyama and Kelen 2007: 24; Keraf 1978: 90-93). The neighbouring languages Kedang and Sika only have free possessor pronouns (compare Samely 1991: 75; Fricke 2014: 39); however, in Timor possessor suffixes are common, as for example in Amarasi (Edwards 2016: 122). On the other hand, a plural suffix and a specificity suffix are not found in other varieties of Lamaholot or Flores-Lembata. For plural marking on nouns using other means, a few scattered cases are attested within the Flores-Lembata group. Alorese has a plural word which has emerged as a consequence of contact-induced grammaticalization involving the neighbouring TimorAlor-Pantar languages (Moro 2017). Hewa, a Sika variety, has a plural word ahan only used for human referents (Fricke 2014: 14). Notably, in Timor morphological marking of plural and specificity or definiteness on nouns appears to be more common. The Austronesian language Amarasi has a plural enclitic $=n($ Edwards 2016: 214, 239). Moreover, the Timor-Alor-Pantar languages Makasae (Huber 2008: 14), Makalero (Huber 2011: 236), and Fataluku (Heston 2015: 21) all have suffixes or enclitics which mark plurality

9 Concerning nominal features, Keraf's wordlists of Central Lamaholot varieties (Keraf 1978: 262-297) provide a hint that the phenomena of plural suffixes, specificity suffixes and double stems spread over the whole area of Central Lamaholot. These distinct morphological features, therefore, set this sub-group within Lamaholot even more apart from the other two sub-groups (compare Section 3 on the internal sub-grouping of Lamaholot). 
on nouns. Plural words are also attested, for example, sia in Tetun Fehan (Van Klinken 1999: 124)..$^{10}$ Morphological marking of specificity or definiteness is reported for Amarasi which has a set of determiner enclitics marking "known definite information" (Edwards 2016: 237), as well as for Rote which uses a suffix or enclitic (Jonker 1908) and for Helong which uses metathesis to express specificity (Balle 2017: 92).

Remnants and variants of the pronominal system in Central Lembata are found right across the Lamaholot area, as well as in other Flores-Lembata languages. Person prefixes on a sub-set of vowel-initial verbs are found in all varieties of Lamaholot, Alorese, Sika and Kedang without exceptions (Klamer 2011: 60; Lewis and Grimes 1995: 605; Nagaya 2011: 103; Nishiyama and Kelen 2007: 31; Samely 1991: 94). Person prefixes spread even wider than Flores-Lembata also being found in Timor, for example, in Amarasi (Edwards 2016: 115). Person suffixes are found to varying degrees in some of the varieties of Lamaholot, Sika and Kedang (Nishiyama and Kelen 2007: 98; Nagaya 2011: 97; Rosen 1986; Samely 1991: 70). In most cases, intransitive subject indexing is more elaborate than object indexing, with the exception of Eastern Adonara Lamaholot, where an elaborate Split-S system has been described (Grangé 2015). One of the conditions determining the marking of $S$ in Eastern Adonara Lamaholot is identified as perfect aspect marking by Grangé (2015: 44), which is probably related to the completive aspect function of person suffixes in Central Lembata Lamaholot. However, no variety has yet been described which has two different sets of person suffixes with the same function, as Set 1 and Set 2 in Central Lembata (compare Table 7). ${ }^{11}$ The neighbouring language Kedang has a set of future tense morphemes (Samely 1991: 88), however, which appears to be very similar in function to the irrealis pronouns in Central Lembata. In Kedang, it is still clear that these pronouns developed from a verb which took personal prefixes.

\section{CONCLUSIONS}

From the comparison of nominal and pronominal features in Central Lembata in Section 6, it becomes clear that some of the features are widely attested in the area, whereas others appear to be scarce or almost unattested. In Table 8, I provide an overview of the features discussed in this article and their spread over the Timor-Flores area. A plus sign means that the features occur widely, although details might differ. A plus in brackets means that the feature only occurs in one variety or is very restricted for other reasons. A minus sign indicates that the feature is unattested; however, it is possible that there are different means to express the function concerned.

10 Note that three of these plural marking cases, Central Lembata, Alores, and Tetun Fehan, originate from a very common grammaticalization pathway of 3PL pronoun to plural marker. $\mathrm{Wu}$ (2017: 61) has found that 3PL pronouns are one of the most common sources for plural words among Austronesian languages.

11 For Kedang, different sets have been reported for subject and object suffixes (Samely 1991: 70). However, the differences are expressed only in 3sG and 3PL and they appear to be optional. 


\begin{tabular}{|c|c|c|c|c|c|c|}
\hline \multirow[t]{2}{*}{ Features } & \multicolumn{5}{|c|}{ Flores-Lembata } & \multirow[t]{2}{*}{ Timor } \\
\hline & $\begin{array}{l}\text { Central } \\
\text { Lembata }\end{array}$ & $\begin{array}{l}\text { Western } \\
\text { Lamaholot }\end{array}$ & Alorese & Kedang & Sika & \\
\hline \multicolumn{7}{|l|}{ Nominal domain } \\
\hline $\begin{array}{l}\text { Alternating } \\
\text { word forms }\end{array}$ & + & - & - & - & - & + \\
\hline $\begin{array}{l}\text { Possessor } \\
\text { suffixes }\end{array}$ & + & + & - & - & - & + \\
\hline Plural suffix & + & - & - & - & - & + \\
\hline Specificity suffix & + & - & - & - & - & + \\
\hline \multicolumn{7}{|c|}{ Pronominal domain } \\
\hline $\begin{array}{l}\text { Personal prefixes } \\
\text { on verbs }\end{array}$ & + & + & + & + & + & + \\
\hline Personal suffixes & + & + & - & + & $(+)$ & - \\
\hline $\begin{array}{l}\text { Suffixes marking } \\
S \text { and } P\end{array}$ & + & $(+)$ & - & + & - & \\
\hline $\begin{array}{l}\text { Personal suffixes } \\
+ \text { aspect }\end{array}$ & + & $(+)$ & - & - & - & - \\
\hline Irrealis pronouns & + & - & - & + & - & - \\
\hline
\end{tabular}

Table 8. Overview of features discussed in this article and their spread over the Timor-Flores area.

From this comparison, it becomes clear that, from a Flores-Lembata perspective, Central Lembata is unique in its way of dealing with nouns, especially alienable nouns. Intriguingly, Central Lembata patterns with Timor in several nominal aspects. Possessor suffixes and morphological plural and specificity marking are found in Central Lembata as well as in languages on Timor. In the same way, two alternating word forms are a feature of Central Lembata as well as of many languages in Timor. However, there is no proof which would allow us to trace the phenomenon of alternating word forms back to a common ancestor of the languages involved. So far, the conclusion has to be that the systems developed independently. Nevertheless, the way they came about needs to be investigated and explained in more detail.

In the pronominal domain, features are more widespread over FloresLembata, as well as in languages in Timor. This pattern, in contrast to the findings in the nominal domain, suggests an inherited pattern which eroded over time in some of the languages but was retained in others. For the verbal prefixes, this assumption appears to hold for the whole Timor-Flores area, whereas the suffixes and the relation of pronouns with aspect and mood might be features of Flores-Lembata only.

In sum, this article has introduced nominal and pronominal features of Central Lembata Lamaholot. On the basis of the comparison of these features with their equivalents in related and geographically close languages, I 
hypothesize that the nominal system of Central Lembata is an independent innovation, whereas the pronominal system, at least in parts, is inherited from a common ancestor. Further research on the languages involved and the exact functioning of the systems will yield a more comprehensive picture of the history of Lamaholot and its neighbouring languages.

\begin{tabular}{ll} 
ABBREVIATIONS \\
1 & First person \\
2 & Second person \\
3 & Third person \\
A & Transitive subject \\
C & Consonant \\
DIST & Distal demonstrative \\
EXCL & Exclusive \\
FOC & Focus \\
INCL & Inclusive \\
IRR & Irrealis \\
LOC & Locative \\
NEG & Negator \\
NP & Noun Phrase \\
P & Transitive Object \\
PL & Plural \\
POSS & Possessive \\
PRF & Perfective \\
PROG & Progressive \\
S & Intransitive Subject \\
SG & Singular \\
SPEC & Specificity \\
UP & Locational for upward direction \\
V & Vowel \\
VP & Verbal Phrase \\
& \\
\hline
\end{tabular}

REFERENCES

Akoli, Marcelinus Yeri Fernandez. 2010. "Lamaholot dialect variations”. MA thesis, Monash University.

Arndt, Paul. 1931. Grammatik der Sika-Sprache. Ende: Arnoldus.

Arndt, Paul. 1937. Grammatik der Solor-Sprache. Ende: Arnoldus.

Balle, Misriani. 2017. "Types of reduplication in Helong, an Austronesian language in Eastern Indonesia", MA thesis, Payap University.

Blust, Robert and Stephen Trussel. 2010. The Austronesian comparative dictionary.

[Retrieved from: http://www.trussel2.com/acd/, accessed on 15-11-2016.] 
Edwards, Owen. 2016. Metathesis and unmetathesis; Parallelism and complementarity in Amarasi, Timor. PhD thesis, Australian National University. [Retrieved from: https://openresearch-repository.anu.edu. $\mathrm{au} / \mathrm{handle} / 1885 / 114481$, accessed on 5-11-2017.]

Elias, Alexander. 2017. “The internal diversity of Lamaholot”. [Term paper, Universiteit Leiden.]

Ernanda. 2017. Phrasal alternation in Kerinci. Utrecht: LOT, Netherlands Graduate School of Linguistics. [LOT Dissertation Series 458; PhD thesis, Leiden University.]

Fernandez, Inyo Yos. 1977. "Bahasa Lamaholot Ile Mandiri”. [Bachelor thesis. Universitas Gadjah Mada.]

Fernandez, Inyo Yos. 1996. Relasi historis kekerabatan bahasa Flores; Kajian linguistik historis komparatif terhadap sembilan bahasa di Flores. Ende: Nusa Indah.

François, Alexandre and Siva Kalyan. Forthcoming. "Freeing the comparative method from the tree model; A framework for historical glottometry", in: Ritsuko Kikusawa and Lawrence Reid (eds), Let's talk about trees; Tackling problems in representing phylogenic relationships among languages. Osaka: National Museum of Ethnology.

Fricke, Hanna. 2014. Topics in the grammar of Hewa; A variety of Sika in Eastern Flores, Indonesia. Munich: Lincom Europa.

Fricke, Hanna. In prep. The history of Lamaholot. PhD thesis, Leiden University. Grangé, Philippe. 2015. “The Lamaholot dialect chain (East Flores, Indonesia)”, in: Malcolm Ross and I Wayan Arka (eds), Language change in Austronesian languages; Papers from 12-ICAL, pp. 35-50. Taiwan: College of Asia and Pacific, The Australian National University.

Heston, Tyler M. 2015. The segmental and suprasegmental phonology of Fataluku. PhD thesis, University of Hawai'i Mānoa.

Holm, John. 2000. An introduction to pidgin and creoles. Cambridge: Cambridge University Press.

Huber, Juliette. 2008. First steps towards a grammar of Makasae; A language of East Timor. Munich: Lincom Europa. [Languages of the World/Materials 195.] Huber, Juliette. 2011. A grammar of Makalero; A Papuan language of East Timor. Utrecht: LOT. [LOT Dissertation Series 279; PhD thesis, Leiden University.] Jonker, J. C. G. 1908. Rottineesch-Hollandsch woordenboek. Leiden: Brill.

Keraf, Gregorius. 1978. Morfologi Dialek Lamalera. PhD thesis, Universitas Indonesia.

Klamer, Marian. 2011. A short grammar of Alorese (Austronesian). Munich: Lincom Europa.

Klamer, Marian (ed.). 2014. The Alor-Pantar languages; History and typology. Berlin: Language Science Press.

Klinken, Catherina van. 1999. A grammar of the Fehan dialect of Tetun. An Austronesian language of West Timor. Canberra: Pacific Linguistics, Australian National University.

Krauße, Daniel. 2016. "A brief grammar of the Eastern Atadei language of Lembata, Indonesia", Linguistik Indonesia 34(2): 113-128. 
Kroon, Yosep. 2016. A grammar of Solor Lamaholot; A language of Flores, Eastern Indonesia. PhD thesis, University of Adelaide.

Lewis, E. Douglas and Charles Grimes. 1995. "Sika", in: Darrell Tryon and Malcolm Ross (eds), Comparative Austronesian dictionary, pp. 601-609. Berlin: Mouton de Gruyter.

Lewis, Paul, Gary Simons, and Charles Fennig. 2016. Lamaholot. Ethnologue; Languages of the World. [Retrieved from: https:/ / www.ethnologue.com/ language/slp, accessed on 13-2-2017.]

Michaelis, Susanne. 2008. Roots of creole structures weighing the contribution of substrates and superstrates. Amsterdam: John Benjamins.

Moro, Francesca. 2017. "The plural word hire in Alorese (Austronesian); Grammatical borrowing from neighboring Papuan languages". [Paper, the Ninth International Austronesian and Papuan Languages and Linguistics Conference (APLL9), Paris, 21-23 June 2017.]

Nagaya, Naonori. 2011. The Lamaholot language of Eastern Indonesia. PhD thesis, Rice University.

Nishiyama, Kunio and Herman Kelen. 2007. A grammar of Lamaholot, Eastern Indonesia; The morphology and syntax of the Lewoingu dialect. Munich: Lincom Europa.

Pareira, M. Mandalangi and E. Douglas Lewis. 1998. Kamus sara Sikka bahasa Indonesia. Ende: Nusa Indah.

Payne, Thomas. 1997. Describing morphosyntax; A guide for field linguists. Cambridge: Cambridge University Press.

Rosen, Joan. 1986. "Phonemes, verb classes and personal endings in Maumere", NUSA: Linguistic studies of languages in and around Indonesia 25: 39-69. [Miscellaneous of Indonesian and Other Languages in Indonesia Part VIII.]

Samely, Ursula. 1991. Kedang, (Eastern Indonesia), some aspects of its grammar. Hamburg: H. Buske. [Forum Phoneticum Bd. 46.]

Samely, Ursula and R. H. Barnes. 2013. A dictionary of the Kedang language; Kedang-Indonesian-English. Leiden: Brill.

Schapper, Antoinette (ed.). 2014. The Papuan languages of Timor, Alor and Pantar Vol. 1. Berlin: Mouton de Gruyter.

Stokhof, W. A. L. 1975. Preliminary notes on the Alor and Pantar languages (East Indonesia). Canberra: Department of Linguistics, Research School of Pacific Studies, Australian National University. [Pacific Linguistics. Series B.]

$\mathrm{Wu}$, Jiang. 2017. "Plural words in Austronesian languages; Typology and history". MPhil thesis, Universiteit Leiden. [Https://openaccess. leidenuniv.nl/handle/1887/45798, accessed on 10-7-2017.] 